\title{
Reindeer in tundra ecosystems: the challenges of understanding system complexity
}

\author{
Feodor V. Kryazhimskii \& Alexey N. Danilov
}

\begin{abstract}
The resilience of tundra ecosystems is limited, with relatively few key biotic components determining the general pattern of the dynamics of these systems. Sustainable use of reindeer pastures, which are natural tundra ecosystems, should take into account interactions within the whole complex of key components. Among the most important are the small herbivorous rodents. For example, during peak densities lemmings may reduce above-ground plant biomass by $50-70 \%$. At the same time, rapid turnover of nutrients in the form of significant amounts of potassium, phosphorus and nitrogen that lemmings excrete in urine promotes vascular plant growth. It is concluded that these kinds of studies are essential for the sustainable management of Russia's grazing lands: 1) comparative studies of productivity, biological diversity and structure of plant communities under the different pressures exerted by the main groups of herbivorous animals (reindeer and small rodents), as well as under varying levels of industrial development; 2) studies of the direct and indirect effects of herbivorous mammals on biological turnover and energy flow within the system; 3 ) studies of the role of industrial contamination on the turnover of nutrients in tundra ecosystems.
\end{abstract}

F. V. Kryazhimskii \& A. N. Danilov, Institute of Plant and Animal Ecology, Ural Division of the Russian Academy of Sciences, 202, 8 Marta St., 620144 Ekaterinburg, Russia.

It is widely recognized that the resilience of tundra ecosystems is limited, resulting in low tolerance to many extrinsic pressures. This feature is a product of 1) low productivity of the dominant plant communities, and 2) the simple structure (including species composition, trophic chains and energy allocation pathways) of tundra ecosystems (Bolshakov et al. 1993). These characteristics are related to thermal instability of permafrost, the relatively short period of evolution of these ecosystems and severe climatic conditions. As a consequence, a relatively few key biotic components determine the general pattern of biological turnover and, consequently, the whole dynamics of tundra ecosystems.

Protection and sustainable use of reindeer pastures, which are in fact natural plant communities, should not ignore the effects caused by other components of tundra ecosystems in addition to reindeer. Moreover, interactions within the whole complex of key components of tundra ecosystems are essential for the long-term, sustained production of reindeer pastures. Among these components, the most important for the vegetative cover are small herbivorous rodents. Lemming species (Dicrostonyx torquatus and Lemmus sibiricus) play the leading role within this group (Thompson 1955; Tikhomirov 1959; Pitelka 1964; Chernyavskii \& Tkachev 1982; Tishkov 1985).

In this paper we take a brief look at this group to demonstrate the importance of examining reindeer habitats as natural ecosystems with complex networks of interrelations. Most data were collected on the Yamal Peninsula. We attempt to show the practical and theoretical importance of a complex approach to studying tundra ecosystems.

\section{The modern state of reindeer pastures in Russia from the viewpoint of an ecologist}

Reindeer herding, a traditional activity in Russia's northern regions, is one of the most important factors affecting the state of vegetative cover 
(Andreev 1972; Polezhaev 1980; Stchelkunova 1992). Extensive studies of pastures aimed toward evaluating their foraging possibilities were started in Russia in the early 1930s (Andreev 1930; Sochava 1931; Gorodkov 1935; Igoshina 1937; Avramchik 1939). The research became focused on processes of pasture degradation and their restoration abilities (e.g. Andreev 1972; Utkin 1977; Polezhaev 1980; Karpov 1991; Dobrinskii 1995). Intensive herding of domestic reindeer leads to dramatic changes in the structure of vegetative cover, lowering its productivity and, consequently, the quality of pastures (Stchelkunova 1992; Polezhaev 1993; Magomedova 1994). In general, excessive grazing pressure suppresses valuable species of lichens, and results in the replacement of typical tundra plant communities by graminoid-dominated ones. On the other hand, since tundra ecosystems developed under some pressure from reindeer (Andreev 1972), complete cessation of grazing also results in changes in the vegetative complex, these changes being negative from the viewpoint of plant productivity and species richness (Karpov 1991). Apparently, both lack of grazing and overgrazing threaten to degrade the structure of tundra ecosystems as grazing lands for reindeer. Therefore, the responses of vegetation to grazing pressure are not linear. This non-linearity provides a basis for understanding what conditions are optimal for maintaining the productivity of tundra vegetation for sustainable reindeer grazing

During the 20th century, grazing pressure of domestic reindeer on their pastures in Russia has increased significantly. For instance, in the Yamalo-Nenets Autonomous Region the numbers of reindeer have doubled since the beginning of the century (Fig. 1). Recently, rapid industrial devel-

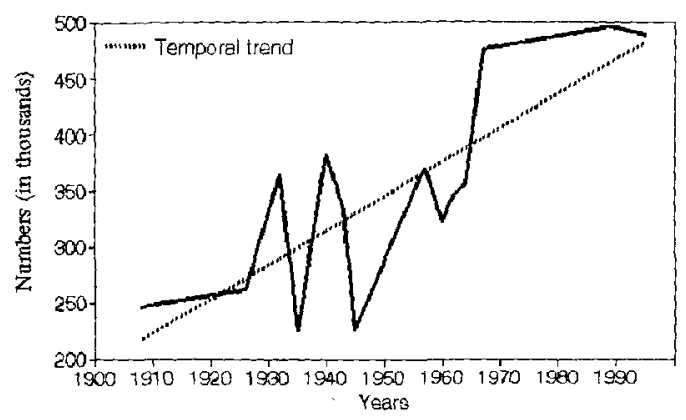

Fig. 1. Numbers of domestic reindeer in the Yamalo-Nenets Autonomous Region during the 20th century (Dobrinskii 1995).
Table 1 . The ratio between fluxes of carbon dioxide from the soil and its intake by vegetation in southern Yamal $\mathrm{g} \mathrm{CO}_{2} / \mathrm{m}^{2}$ (Dobrinskii et al. 1983).

\begin{tabular}{lccc}
\hline Plant community & $\begin{array}{c}\text { Intake of } \mathrm{CO}_{2} \text { flux from } \\
\text { the soil }\end{array}$ & $\begin{array}{c}\text { Release/ } \\
\text { intake }\end{array}$ \\
\hline $\begin{array}{l}\text { Alluvial cereal-sedge } \\
\text { meadow }\end{array}$ & 25 & 15.7 & 0.63 \\
$\begin{array}{l}\text { Moss tundra with } \\
\text { Rubus chamaemorus } \\
\text { and Carex spp. }\end{array}$ & 6.9 & 6.4 & 0.93 \\
$\begin{array}{l}\text { Sphagnum bog with } \\
\text { dwaft shrubs and } \\
\text { cottongrass }\end{array}$ & 4.2 & 4.9 & 1.17 \\
\hline
\end{tabular}

opment has added to the pressure generated by the increasing herds. In the Russian North a unique combination of factors, both natural and artificial, are affecting the natural ecosystems. These ecosystem level changes may have consequences at the global level through their alteration of atmospheric gas fluxes. For example, in situ studies of $\mathrm{CO}_{2}$ fluxes in different types of plant communities in southern Yamal showed that in typical tundra communities the photosynthetic intake of carbon dioxide by vegetation in the peak of the growth season was practically equal to its release by soil respiration, while in meadows the uptake of $\mathrm{CO}_{2}$ was significantly greater than its release (Table 1). These results suggest that if typical tundra communities are replaced by meadow-like ones, dominated by cereals and sedges, as a consequence of heavy grazing pressure, the general balance of carbon in Arctic and sub-Arctic regions may be altered.

\section{The role of small rodents in tundra ecosystems}

Among herbivorous animals, reindeer and small rodents have the most visible influence on the vegetation of tundra ecosystems. The role of small rodents in shaping the appearance of tundra ecosystems in Russia was first described by Tikhomirov (1959). Judging by rough estimations of the mass of dry matter removal by reindeer (Polezhaev 1993) and lemmings (Danilov 1995), their impact on the vegetation is quantitatively similar. However, the character of this influence is different in reindeer and rodents. In addition to the differences in the diet (small rodents make little use of lichens), the temporal and spatial character- 
istics of the impact differ between these two groups of mammals.

Lemming populations fluctuate, reaching high density at the peak phase (up to 200-300 individuals/ha), with a biomass of about $5-8 \mathrm{~kg}$ / ha. In years of peak density lemming may reduce above-ground plant biomass by 50-70\% (Thompson 1955; Pitelka 1964; Batzly 1974). During periods of low density, when the impact of rodents on vegetation is practically absent, accumulation of dead parts of plants occurs. (Kiryustchenko 1979; Danilov 1995). The pressure of rodents on the vegetative cover, therefore, oscillates over time, in contrast to that of reindeer. This cyclic alteration of herbivore pressure was shown to be an important factor in the dynamics of tundra vegetation in the southern Yamal (Peshkova 1977).

Rodents also play an important role in the turnover of nutrients in the tundra. It is clear from Fig. 2 that significant amounts of potassium, phosphorus and nitrogen that lemmings consume in their food are rapidly released in their unine.

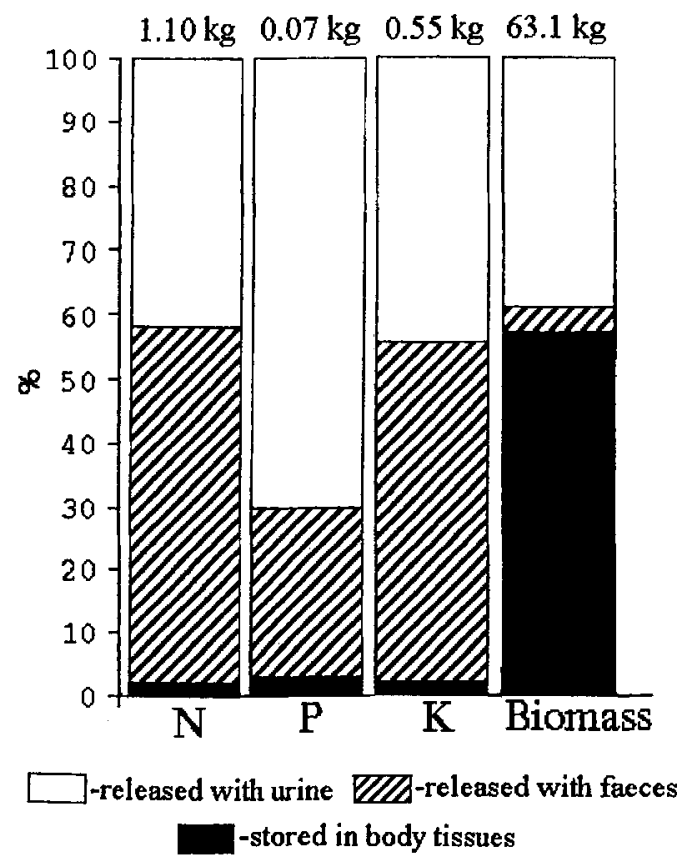

Fig. 2. Intake and release of nutrients (N, P and $\mathrm{K})$ and plant biomass by lemmings (Lemmus sibiricus and Dycrostonix torquatus) during a population cycle in southern Yamal (Danilov 1995). $\mathrm{Kg}$ values indicate the absolute value of nutrients involved in turnover, per ha. Column segements represent proportion (\%) of different components of turnover for each nutrient.
This rapid turnover of nutrients can be viewed as natural fertilization, promoting vascular plant growth. The rate of decomposition of faeces of herbivorous mammals is, however, slow - usually not exceeding $2 \%$ of dry matter per year (Malafeev \& Kryazhimskii 1990; Mukhin 1993). Thus utilization of faecal nutrients by plants is delayed. This temporal complexity of biotic turnover in tundra is not well known and should be carefully examined.

\section{Prospects for further studies}

It follows from the above that there is an urgent need to study tundra reindeer pastures as components of whole ecosystems. There is little hope that sustained production of reindeer pastures can be achieved with the aid of agricultural measures, such as fertilization, seeding etc., since economic justification for such measures is questionable.

Reindeer herding remains an important use of biological resources in the Russian North. The state and dynamics of the natural ecosystems upon which herding is based are dependent on a complex of interactions between a variety of extrinsic and intrinsic factors. However, since tundra ecosystems are relatively simple, it is possible to outline several key biotic components determine the general pattern of its dynamics (Schwarz 1971). Studying the responses of these components to changes (which are not simple and linear) in both intrinsic and extrinsic factors (including the inevitable continuation of industrial development) should provide information essential for the sustainable management of Russia's reindeer grazing systems. We recommend the following research emphases:

1) Comparative studies of productivity, biological diversity, and structure of plant communities under the different pressures exerted by the main groups of herbivorous animals (reindeer and small rodents), as well as under varying levels of industrial development.

2) Study of the direct and indirect effects of herbivorous mammals (both reindeer and rodents) on biological turnover and energy flow within the system.

3) Study of the role of industrial contamination on the turnover of nutrients in tundra ecosystems.

These studies should be based on the modern system approach, taking into account both tem- 
poral and spatial dynamics of the subjects of the studies.

Acknowledgements. - We are grateful to our colleagues from the Institute of Plant and Animal Ecology, Ural Division of RAS: N. V. Peshkova, L. N. Dobrinskii, Yu. M. Malafeev, V. A. Mukhin and M. A. Magomedova for great help with field work or in subsequent discussions. The study was supported by the Russian Fund for Fundamental Research (grant no. 99-04-49030) and by the Federal Programme, "Biodiversity."

\section{References}

Avramchik, M. N. 1939: Zimnee pitane olenei na Yamal'skom Severe. (Winter feeding of reindeer in northern Yamal.) Trudy NII polyarnogo zemledeliya, zhivotnovodstva $i$ promyslovogo hozyaistva, Ser. Olenevodstvo (Proc. Res. Inst. Polar Agric., Ser. Reindeer Breeding) 4, 7-66.

Andreev, V. N. 1930: Geobotanicheskoe issledovanie tudroyyh olen'ih pastbistch. (Geobotanical studies of tundra reindeer pastures.) Sovetskiy Sever 5, 101-108.

Andreev, V. N. 1972: Izucheniye antropogennykh vozdeistviy na rastitel'nost' Arktiki i Subarktiki. (Studies of anthropogenic influence on the vegetation of the Arctic and subArctic.) In: Studies of biogeocoenoses of tundra and foresttundra. Pp. 44-49. Leningrad: Nauka Publ.

Batzly, G. O. 1974: Relationships between lemmings and vegetation in tundra ecosystems. In: Proceedings of the First International Theriological Congress. Vol. I. Pp. 47-48. Moscow.

Bolshakov, V. N., Dedkov, V. S., Dobrinskii, L. N., Korytin, N. S., Kryazhimskii, F. V., Magomedova, M. A., Nifontova, M. G., Semerikov, L. F. \& Shiyatov, S. G. 1993: Dynamics of tundra ecosystems in the West-Siberian sectors of Arctic: signs of crisis. Abstracts of the conference: Global Change and Arctic Terrestrial Ecosystems. P. 34. Oppdal (Norway).

Chernyavskii, F. B. \& Tkachev, A. V. 1982: Populyatsyonnye tsykly lemmingov v Arktike: ekologicheskiye i endokrinotogicheskiye aspekty. (Population cycles of lemmings in the Arctic: population and endocrinology aspects.) Moscow: Nauka Publ.

Danilov, A. N. 1995: The role of lemmings in the biological cycle in southern Yamal. Russ. J. Ecol. 26(3), 203-207.

Dobrinskii, L. N. (ed.) 1995: Priroda Yamala. (The nature of Yamal.) Ekaterinburg: Nauka Publ.

Dobrinskii, L. N., Davydov, V. A., Kryazhimskii, F. V. \& Malafeev, Yu. M. 1983: Funktsional'nye svyazi melkih mlekopitayustchih s rastitel'nost'yu v lugovyh biogeocenozah. (Functional links of small mammals with vegetation in meadow biogeocoenoses.) Moscow: Nauka Publ.

Gorodkov, V. N. 1935: Rastitel'nost' tundrovoi zony SSSR. (Vegetation of the tundra zone of the USSR.) Moscow: USSR Academy of Sciences.

Igoshina, K. N. 1937: Pastbistchnye korma i kormovye sezony v olenevodstve Priural'ya. (Pasture food and feeding seasons in the reindeer herding of pre-Urals.) Sovetskoye olenevodstvo I0, 125-195.

Karpov, N. S. 1991: Vliyanie vypasa olenei na rastitel'nost' subarcticheskoi tundry $v$ Yakutii. (The effect of reindeer grazing on the vegetation of pastures in the sub-Arctic tundra of Yakutiya). Yakutsk: USSR Academy of Sciences.

Kiryustchenko, S. P. 1979: Vozdeistvie lemmingov na rastitel'nost' arkticheskoi ekosystemy. (The influence of lem- mings on the vegetation of an Arctic ecosystem: the example of Vrangel Island.) In F. B. Chernyavskii (ed.): Ekologiya polyovok i zemleroyek na Severo-Vostoke Sibiri. (Ecology of voles and shrews in north-west Siberia.) Pp. 39-45. Vladivostok: USSR Academy of Sciences.

Magomedova, M. A. 1994: Lishainiki predtundrovyh lesov Zapadnoi Sibiri. (Lichens of pre-tundra forests of west Siberia.) Botanicheskii Zhurnal 79(11), 1-11.

Malafeev, Yu. M. \& Kryazhimskii, F, V. 1990: The rate of decomposition of moose excrements in the subarctic. Proceedings of the Third International Symposium on Moose. P. 68. Syktyvkar: USSR Academy of Sciences.

Mukhin, V. A. 1993: Biota ksilotrofnyh bazidiomitsetov Zapadnoi Sibiri. (Biota of xylotrophic basidiomycetes of west Siberia.) Ekaterinburg: Nauka Publ.

Peshkova, N. V. 1977: Produktivnost' rastitel'nyh soobstchestv statsionara "Khadyta" i vliyaniye gryzunov na travyanistyi pokrov poligonov. (Productivity of plant communities of the Khadyta Station and the effect of rodents on the polygon testing ground.) In N. N. Danilov (ed.): Biotsenoticheskaya Rol' Zhyvotnykh $\vee$ Lesotundre Yamala. (Biocenotic role of animals in Yamal forest tundra.) Pp. 134-145. Sverdlovsk: USSR Academy of Sciences.

Pitelka, F. A. 1964: The nutrient recovery hypothesis for Arctic microtine cycles. In D. J. Crisp (ed.): Grazing in terrestrial and marine environments. Pp. 55-56. Oxford: Oxford University Press.

Polezhaev, A. N. 1980: Izmemeniye rastitel' nosti na pasbistchakh Chukotki pod vliyaniyem vypasa. (Changes of vegetation at the pastures of Chukotka under the influence of grazing.) Ekologiya 5, 5-13.

Polezhaev, A. N. 1993: Rastitel'nost' Dal'nego Vostoka i eye ispol'zovaniye v olenevodstve. (Vegetation of the Far East and its usage in reindeer herding.) DSc thesis, Institute of Plant and Animal Ecology, Ural Division of Russian Academy of Sciences.

Schwarz, S. S. 1971: Populyatsionnaya struktura biogeotsenoza. (Population structure of a biogeocoenosis.) lzvestiya $A N$ SSSR, Ser. Biol., 4, 458-493.

Sochava, V. B. 1931: Tundrovedeniye i yageleustroistvo. (Tundra science and lichen management.) Sovetskii Sever I, 78-84.

Stchelkunova, R. P. 1992: Vozdeistviye promyshlennosti i transporta na olen'i pastbistcha: na primere Taimyra. (Effect of industry and transport on reindeer pastures: the example of Taymyr.) Geografiya i prirodnye resursy 4, 49-55.

Thompson, D. Q. 1955: The role of food and cover in population fluctuation of the brown lemming at Point Barrow, Alaska. Trans. North Am. Wildl. Conf. 20, 166-176.

Tikhomirov, B. V. 1959: Vzaimosvyaz' zhivotnogo mira i rastitel'nogo pokrova tundry. (Interrelation between animals and tundra vegetative cover.) Moscow: Nauka Publ.

Tishkov, A. A. 1985: Rastitel'noyadnye zhivotnye v ekosistemah tundry. (Herbivorous animals in tundra ecosystems.) In V. E. Sokolov (ed.): Mlekopitayustchive $v$ nazemnykh ekosistemakh. (Mammals in terrestrial ecosystems.) Pp. 3866. Moscow: Nauka Publ.

Utkin, V. V. 1977: Ob izmenenii rastitel'nosti na lesotundrovyh pastbistchah r. Pechory vsledstviye mnogoletnego vypasa olenei. (On the change of vegetation in forest-tundra pastures of the Pechora River as a consequence of long-term grazing of reindeer.) In: Meloratsiya zemel' Krainego Severa (Melioration of territories of the far North.) Pp. 243-250. Moscow: Agropromizdat. 